\title{
FEASIBILITY STUDY FOR CREATION MEAT SAUSAGE FACTORY IN NYALA CITY, SOUTH DARFUR STATE, SUDAN
}

\author{
Adam Mohamed Abdelrhman Sabon \\ PHD Student \\ Faculty of post graduates \\ Nile Valley University, Atbara, Sudan
}

\author{
M.I.Shukri \\ Professor \\ Faculty of Mechanical Engineering \\ Nile Valley University, Atbara, Sudan
}

\begin{abstract}
-- the aim of this study is to investigate the feasibility of a sausage factory in Nyala city, south darfur in Sudan. The paper considers the technical, technological economical and financial aspects in the project feasibility analysis. The data and statistics were taken from government sources mainly from ministry of industrial, ministry of finance, economy and manpower, investment promotion commission and ministry of animal resources of the state, and the data was analyzed technically, economically using investment appraisal techniques like NBC, NPV and IRR (\%).

The results indicated that the meat sausage factory is technically feasible with a viability stock of livestock, land area for establish factory and it can be easily imported machines and equipment from the abroad. Socially feasible, the project can provide additional employment opportunities and increase the income of the local and regional community. Economically, feasible with financial indicators values NBC ratio of 7.4, NPV of 51353.09US\$ and IRR of $40 \%$.
\end{abstract}

Keywords--Nyala city of south Darfur state, feasibility study, meat sausage, creation factory.

\section{INTRODUUCTION}

Meat is defined as the edible part of the skeletal muscle of an animal that was healthy at the time of slaughter [1]. Meat is especially rich in proteins, vitamins, and minerals and is an important element in human diet [2].

Sudan has a huge animal resource, estimated to be more than 106 million head, 30.37 million cattle, 4.80 million camel, 40.21 million sheep and 31.32 million goats [3]. Meat and meat products are excellent sources of protein, fat, minerals and vitamins which are important components of the diet for human [4].

Sausage is derived in the latin word 'Salsus' meaning salted or preserved by salting [5].

Sausage is one of the old product in which fresh comminute meat is modified by various processing methods to yield desirable organoleptic and keeping properties. Meat sausage is more economical than whole meat since they are manufactured from low quality meats and other ingredients. A part from being more economical, sausage product is also found to be of good nutritional values and contains significant amount of high quality protein [6].

Sausage making evolved as an effort to economize and preserve meat which could not be consumed immediately after slaughter [7]. This practice could be traced back to the ancient Greeks and Romans who made sausages which were usually plain and un spiced [8]. Sausage production has been in existence for twenty centuries [9] and over the years, there are some modifications in almost all areas of production although the principles remain the same. Therefore, this research is to investigate the feasibility of a sausage factory in Nyala city, south Darfur in Sudan.

\section{RESEARCH METHODS}

\section{- Research location}

The research has been conducted in the Nyala city capital of south Darfur state in Sudan. South Darfur state is one of the 18 th states in Sudan and it located $1200 \mathrm{~km}$ far from Khartoum the national capital in south-western part of the country between latitudes (8: 30-13: 30) degrees north and longitudes (22: 28-28) degrees east. It is bordered to the north by the State of North Darfur, to the West by the State of West Darfur and the Central African Republic, to the South by the States of Western and Northern Bahr el Ghazal in South Sudan and to the East by the State of Eastern Darfur. The main activities are the trade, agriculture and livestock. Most of the populations in south Darfur state are depending on the agriculture and livestock sector in their economic life.

\section{- Data sources}

The type of research is descriptive; data were collected from viable sources like ministry of industrial, investment promotion commission, finance ministry and websites etc. Data was analyzed by using project evaluation techniques like NBC, NPV and IRR (\%).

\section{PROJECT FEASIBILITY ANALYSIS (VARIABLES)}

- Technical analysis 


\section{International Journal of Engineering Applied Sciences and Technology, 2020 \\ Vol. 5, Issue 7, ISSN No. 2455-2143, Pages 7-11 \\ Published Online November 2020 in IJEAST (http://www.ijeast.com)}

According to [10], the technical analysis variables comprise: project location, project capacity production, and raw materials, building, construction, machines and technologies required.

\section{- Economic analysis}

The socio-economic aspect analyzes the positive impacts of the project towards communities [11]. The socio-economic variables such as job opportunities increase of the local and regional communities' incomes increase of the local and regional governments' incomes, and increase of the local and regional GDP.

\section{- Financial Analysis}

According to [12], the financial analysis includes variables such, project operating cost, project operating revenue, and project operating benefit.

\section{- Net Benefit Cost Ratio (BCR)}

Net benefit cost ratio is used to compare the positive net present income with the negative net present income. If $\mathrm{Net}$ $\mathrm{B} / \mathrm{C}$ is greater than 1 , the project is feasible; but if Net $\mathrm{B} / \mathrm{C}$ is smaller than 1 , the project is not feasible. Net $\mathrm{B} / \mathrm{C}$ formula is as follows [13].

$$
\mathrm{BCR}=\frac{\sum_{\mathrm{t}=1}^{\mathrm{n}} \frac{\mathrm{B}_{\mathrm{t}}}{\left(1+\mathrm{r}^{2}\right)^{\mathrm{t}}}}{\sum_{\mathrm{t}=1}^{\mathrm{n}} \frac{\mathrm{C}_{\mathrm{t}}}{(1+\mathrm{r})^{2}}}
$$

Where:

$\mathrm{B}_{\mathrm{t}}=$ benefits received in a year $(\mathrm{t})$;

$\mathrm{C}_{\mathrm{t}}=$ costs incurred in a year $(\mathrm{t})$;

$\mathrm{r}=$ discount rate

$\mathrm{n}=$ number of years in the evaluation period.

\section{- Net Present Value (NPV)}

Is the difference between the present value of cash inflows and the present value of cash outflows? If NPV is positive, the project is feasible; but if NPV is negative, the project is not feasible [16]. NPV formula is as follows [14].

$$
\mathrm{NPV}=\sum_{\mathrm{t}=1}^{\mathrm{n}} \frac{\mathrm{B}_{\mathrm{t}}-\mathrm{C}_{\mathrm{t}}}{(1+\mathrm{r})^{\mathrm{t}}} \ldots \ldots \ldots \ldots \ldots \ldots \ldots
$$

Where:

$$
\begin{aligned}
B_{t} & =\text { benefits received in a year }(t) ; \\
C_{\mathrm{t}} & =\text { costs incurred in a year }(\mathrm{t}) ; \\
\mathrm{r} & =\text { discount rate } \\
\mathrm{n} & =\text { number of the year in evaluation period }
\end{aligned}
$$

- Internal Rate of Return (IRR).

Is the discount level that makes Net Present Value equal to zero [15]? If IRR is greater than the current interest level, the project is feasible. The formula for IRR is as follows [16].

IRR $=r_{1}+\frac{\left(r_{2}-r_{1}\right) N P V_{1}}{N P V_{1}-N_{2}}$

Where:

$\mathrm{r}_{1}=$ discount rate of $\mathrm{NPV}_{1}$

$\mathrm{r}_{2}=$ discount rate of $\mathrm{NPV}_{2}$

\section{RESULTS AND DISCUSSION}

\section{1 project feasibility analysis}

\subsubsection{Technical analysis}

\subsubsection{Project location and period analysis}

The location of the project has been chosen in Nyala city capital of south Darfur state based on resources base approach, where the quantity of meat, electricity and water required can be met. However, the Commercial department will be located in Nyala city. This choice has been made based on market base approach. The duration of the project has been set at five years.

\subsubsection{Production capacity and raw material analysis}

The total production of the factory will be about $1000 \mathrm{~kg}$ ( $850 \mathrm{~kg}$ lean beef, $150 \mathrm{~kg}$ mutton fat) per day. Based on the product formula, factory's daily production requires five cattle's with $200 \mathrm{~kg}$ weight, 2000 packs of $0.5 \mathrm{~kg}$ sausage. In addition to non-meat intergradient such as $2 \mathrm{~kg}$ of garlic, $2 \mathrm{~kg}$ of salt and. All of these raw materials are available in the local and national markets.

\subsubsection{Building and infrastructure analysis}

Based on the factory's activities, the suggested building required $250 \mathrm{~m}^{2}$. The building area use by the production line, warehouse and cold storage, management office and commercial office shall be $70 \mathrm{~m}^{2}, 40 \mathrm{~m}^{2}, 16 \mathrm{~m}^{2}$ and $24 \mathrm{~m}^{2}$ respectively. This building will be located in Nyala city Centre. The factory communication will be based on cell phone and internet. Cell phone will be used for both internal and external communications. Three mobile operators are available in the state, namely, Zain, MTN, and Sudani.

\subsubsection{Machines and technologies analysis}

Sausage processing starts with operations such as meat arrived is checked and their weight determined by means of a scale. The second step of the processing sausage is chilling (cooling device) depends largely upon the capacity and character of processing conducted. The temperature of the chiller should be $0^{\circ}$ to $4^{\circ} \mathrm{C}$. The third step of production sausage is grinding the ingredients by meat grinding machine (Fig.1) this stage reduce the meat ingredient into small uniformly sized particles. The fourth step of production sausage is manufacturers carefully control in the blending meat and non-meat ingredients to create the desired characteristics for specific sausage formulation (Fig.2). The fifth step of processing sausage is stuffing the blended ingredients may be bulk packed or they may be extruded into a casing after the blending is complete (Fig.3). The sixth step of processing sausage is filler machine for stuffing kinds of sausage (Fig.4). the seventh step of processing sausage is 
smoking machine is used to dry and cure the meat for making smoked sausage and impart flavors and aroma to the final product (Fig.5). The six step of processing sausage is packing and storage the fresh sausage is sometimes packed for sale to customer (Fig.6). The factory will need equipment's such as the office equipment's comprise computers, printers, chairs, tables, calculators, etc.
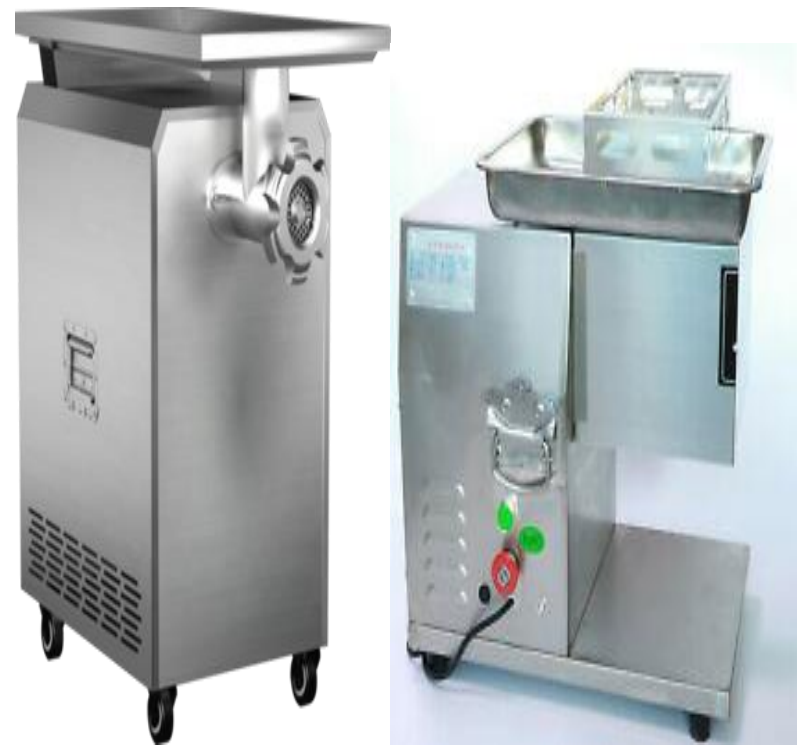

Figure 1: Meat grinder machine Figure 2: cutter (chopper) machine
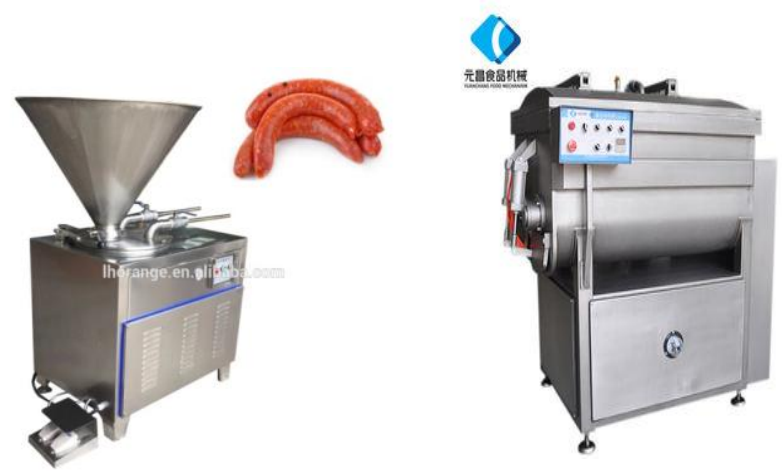

Figure3. Sausage stuffing machine

Figure 4.Sauage filling machine

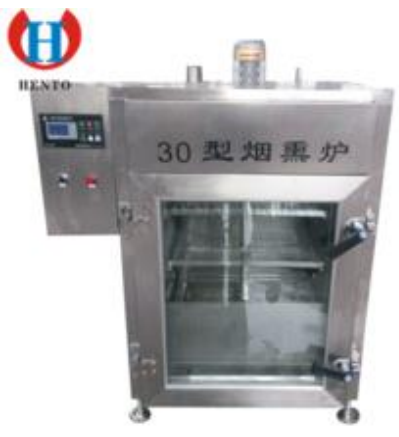

Figure5.Smoked sausage oven

HORin

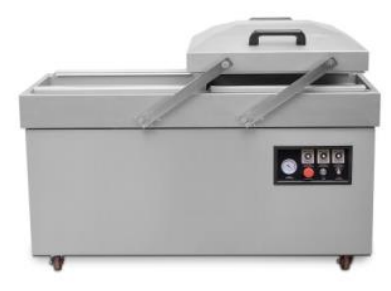

figure 6. Sausage packing machine

\subsubsection{Human resources skills required analysis}

The human resources skills required for the meat sausage processing is more technical and technological, yet those required for the commercial department are more strategic. Therefore, the responsible of the production line should have knowledge related to human resources management and knowledge related to sausage manufacturing system. These required skills may not be available in Nyala city of south Darfur state. In this case, the factory should hire skills from Khartoum and train the other new technician as better as possible.

\subsection{Economic analysis}

South Darfur state is rich of livestock to economically operate more meat processing factory. This is true for both cattle and lambs multispecies meat processing factory may be economically feasible.

Creation meat sausage processing factory is economically feasible. There is sufficient land, infrastructure, labor, etc. for a feedlot to operate in that part of the state. There are also a sufficient number of cattle in this part of the state.

\subsection{Financial analysis}

The initial investment (Io) required to start this project is 30211.75US\$. This amount already takes into account the purchases of the land, machines and equipment's and the costs of building constructions. Table 1 show factory's cash flow projection in USS, the operating cost and operating revenue during the five years are assumed constant and the materials depreciations are calculated by supposing that the building, machines, and equipment loss 5, 10, and 20\% per year of their initial values, respectively.

Table1. Factory's cash flow projection in US\$

\begin{tabular}{|l|l|l|l|l|l|l|}
\hline Description & $\begin{array}{l}\text { Yea } \\
\text { r 0 }\end{array}$ & Year 1 & Year 2 & Year 3 & Year 4 & Year 5 \\
\hline Investment(Io) & \multicolumn{6}{|l|}{30211.75} \\
\hline Operating cost & \multicolumn{7}{|l|}{} \\
\hline Variable cost & & $\begin{array}{c}42081 \\
1\end{array}$ & 420811 & 420811 & 420811 & 420811 \\
\hline
\end{tabular}




\begin{tabular}{|l|c|c|c|c|c|c|}
\hline \multicolumn{1}{|c|}{ Fixed cost } & & $\begin{array}{c}17115 . \\
5\end{array}$ & $\begin{array}{c}17115 . \\
5\end{array}$ & $\begin{array}{c}17115 . \\
5\end{array}$ & $\begin{array}{c}17115 . \\
5\end{array}$ & 17115.5 \\
\hline $\begin{array}{l}\text { Total } \\
\text { production }\end{array}$ & & $\begin{array}{c}30000 \\
0\end{array}$ & 300000 & 300000 & 300000 & 300000 \\
\hline Product price & & 1.6 & 1.6 & 1.6 & 1.6 & 1.6 \\
\hline $\begin{array}{l}\text { Operating } \\
\text { revenue }\end{array}$ & & $\begin{array}{c}48000 \\
0\end{array}$ & 480000 & 480000 & 480000 & 480000 \\
\hline $\begin{array}{l}\text { Operating } \\
\text { profit }\end{array}$ & & 42074 & 42074 & 42074 & 42074 & 42074 \\
\hline Taxes (20\%) & & 8414.8 & 8414.8 & 8414.8 & 8414.8 & 8414.8 \\
\hline EAT & & $\begin{array}{c}33659 . \\
2\end{array}$ & $\begin{array}{c}33659 . \\
2\end{array}$ & $\begin{array}{c}33659 . \\
2\end{array}$ & $\begin{array}{c}33659 . \\
2\end{array}$ & 33659.2 \\
\hline Depreciation & & 1083.2 & 1083.2 & 1083.2 & 1083.2 & 1083.2 \\
\hline NICF & & 34742. & 34742. & 34742. & 34742. & 34742.4 \\
& 4 & 4 & 4 & 4 & \\
\hline
\end{tabular}

EAT: Earning After Tax; NICF: Net Income Cash Flow

Table 2 shows the financial indictors values which indicate to the feasibility of the project the first indictor to evaluate the feasibility of the project $t$ according to their rules that states:

The first indictor to evaluate the feasibility of the project is net benefit cost ration (NBC), is greater than one the project is feasible as shown in the table 2, the factory net benefit cost ratio will be 7.4.

The second indictor to evaluate the feasibility of the project is net present value (NPV). It is present the difference between the sum of the net benefits and the sum of the net costs of the project. Where net present value is positive as shown in the table 2 the project is feasible. This means that the factory will be able to provide a net amount of 51353.09 US\$ within five years of production.

The third indicator used in the financial analysis is internal rate of return(IRR \%) is equal to $40 \%$ as shown in the table 2 , which is greater than the current interest rate of $10 \%$ per year, the project is feasible.

Table 2 Financial indicators' values

\begin{tabular}{|l|c|c|c|}
\hline Indicator & NBC & NPV & IRR \\
\hline Value & 7.4 & 51353.09 & $40 \%$ \\
\hline
\end{tabular}

\section{CONCLUSION}

Feasibility analysis of creation sausage factory in Nyala, south Darfur, Sudan, showed that the sausage factory is technically, technologically and economically feasible with rich of livestock in the state to economically operate more meat processing factory. There is sufficient land, infrastructure, labor, etc. for a feedlot to operate in that part of the state and it's possible to imported machines and equipment from abroad. All financial indicators (NBC, NPV and IRR \%) used in analysis highlighted that the creation of the sausage factory is feasible.

\section{ACKNOWLEDGEMENTS}

The author likes to express deepest gratitude to Professor Mohamed Ibrahim Shukri for his contribute, suggest and helpful, to bring out this paper in its current form.

\section{REFERENCE}

[1] CFDAR.(1990) Canadian Food and Drugs Act and Regulations. With amendments. Section 14, Paragraph B.14.002.[S],( pp. 64).

[2] P. M. D. C. C. Pereira; and A. F. D. R. B.(2013). Vicente, "Meat nutritional composition and nutritive role in the human diet," Meat Science, vol. 93, no. 3, (pp. 586-592).

[3] Elhassan, I.H., et al.(2019). Quality Characteristics of Beef Sausage Incorporated with Chickpea Flour. Journal of Academia and Industrial Research (JAIR), 2019. 7(12): (pp. 169).

[4] Eltom. W.M.(2017). Assessment of microbial growth and oxidative rancidity of beef sausage incorporated with mint (Menthaspicata).Powder.Doctoral Dissertation, Khartoum University. Retrieved from http: //www.Khartoum University.

[5] Sausage making (2009).Wilkipedia, the free encyclopedia from www.wikimedia.org. retrieved January 18,2009.

[6] Mohan,A.;(2014).Basics of sausage making, Formulation, Processing and safety. UGA Extension Bulletin, 1437:( pp. 5-8).

[7] Abdolghafour, B.; and A. Saghir.(2008) Development in sausage production and practices-A review. Journal of meat science and technology, 2(3):( pp. 40-50).

[8] Sausage.(2008).The Columbia Encylopedia, sixth edition. Retrieved January 15,2009 from Encyclopedia.com. http://encyclopedia.com/doc/1E1- sausage.htm.

[9] Sausage History, (2009).History of the Sausage . www.britshbarbecue.co.uk

[10] Hasan, S. and Suryahadi.(2012). Feasibility study of broiler breeding farm in Bogor regency-Indonesia, Journal.ipb.ac.id. 7(1): (pp54-63).

[11] Glen, E.;and Burton, W.,(1997). Measuring economic impacts of Projects and Programs.Economic Development Research, Boston. Page: (pp1-253).

[12] Xiao, L.M.;and Pieter, V.D.(2010).Financial and economic feasibility of decentralized wastewater reuse systems in Beijing. Water science \& Technology Journal. 61(8): (pp1-14).

[13] Yusuf, T., S. Tiamiyu.;and R. Aliu.(2016) Financial analysis of poultry production in Kwara State, Nigeria. African Journal of Agricultural Research, 11(8):( pp.718723).

[14] Huang, S.-R., et al.(2014). Evaluating the productivity and financial feasibility of a vertical-axis micro-hydro 
energy generation project using operation simulations. Renewable energy, 66:( pp. 241-250).

[15] Chiang, Y.H., E.W. Cheng, and P.T. Lam.(2010). Employing the net present value-consistent IRR methods for PFI contracts. Journal of construction engineering and management, 136(7): (pp. 811-814).

[16] Ibrahim Y.(2003). Business feasibility study, revision editing. Chapter V: Systematic business feasibility study. :(pp.1-192). 